\title{
Influence of continuous steel casting conditions on behavior and stability of liquid mold slag during slab casting - physical modeling
}

\author{
Wpływ warunków ciągłego odlewania stali \\ na zachowanie i stabilność ciekłego żużla \\ krystalizatorowego podczas odlewania wlewków płaskich - \\ modelowanie fizyczne
}

\begin{abstract}
This article presents the results of the physical modeling of the continuous casting of steel slabs in a mold. The experiments focused on the assessment of the shape and stability of the liquid mold slag layer, which was reproduced in studies using silicone oil. The experimental tests were carried out for two different geometries of the submerged entry nozzle, two extreme submergence depths of the submerged entry nozzle $(0.215$ and $0.295 \mathrm{~m})$, and two extreme casting speeds ( 1.0 and $1.6 \mathrm{~m} / \mathrm{min}$ ) used in industry. For each variant of the experiment, photographic documentation of the oil layer's behavior was presented and discussed. The research was supplemented with a visualization of the flow structure using a marker for the selected variant of the experiment.
\end{abstract}

Keywords: continuous steel casting, mold, submerged entry nozzle, mold slag, physical modeling

\section{Streszczenie}

W artykule przedstawiono wyniki modelowania fizycznego ciągłego odlewania stalowych wlewków płaskich w krystalizatorze. Eksperymenty koncentrowały się na ocenie kształtu i stabilności warstwy ciekłego żużla krystalizatorowego, odwzorowanego w badaniach za pomocą oleju silikonowego. Badania modelowe przeprowadzono dla dwóch różnych geometrii wylewu zanurzeniowego, dwóch skrajnych głębokości zanurzenia wylewu $(0,215 \mathrm{~m}$ i 0,295 m) oraz dwóch skrajnych prędkości odlewania $(1,0 \mathrm{~m} / \mathrm{min}$ i 1,6 $\mathrm{m} / \mathrm{min})$ stosowanych w przemyśle. Dla każdego wariantu eksperymentu zaprezentowano i omówiono dokumentację fotograficzną zachowania się warstwy oleju. Badania uzupełniono znacznikową wizualizacją struktury przepływu dla wybranego wariantu eksperymentu.

Słowa kluczowe: ciągłe odlewanie stali, krystalizator, wylew zanurzeniowy, żużel krystalizatorowy, modelowanie fizyczne

Marcin Bielnicki, Jan Jowsa: Czestochowa University of Technology, Faculty of Production Engineering and Materials Technology, Department of Metals Extraction and Recirculation, Czestochowa, Poland; bielnicki.marcin@wip.pcz.pl, jowsa.jan@wip.pcz.pl 


\section{Introduction}

More than 95\% of the steel semi-finished products manufactured in the year 2016 around the world were cast by the continuous steel casting method (CSC) [1]. The easy change of the cast strand dimensions, the wide range of the casting process parameters and steel grades being cast, the possibilities of casting high-quality products, and the economic aspects caused a gradual replacement of traditional ingot casting by CSC. Despite the huge difference in technological advancement between the first CSC machines and those of today, the possibilities for further increasing the efficiency of the CSC process are still being sought.

One of the concepts to improve the unit cost of steel production relies on increasing the casting speed. For this purpose, a special funnel-shaped mold for thin slab casting has been developed, enabling casting with speeds exceeding $5.0 \mathrm{~m} / \mathrm{min}$ [2-5]. Moreover, attempts have also been made to improve casting efficiency by increasing the speed in the casting of conventional slabs. However, increased casting speeds will lead to increased surface velocity and meniscus fluctuations, shell bulging, worsening of the shell lubrication conditions, and increased tendencies of slab surface cracking $[6,7]$.

It is well-known that increase the casting speed may be one of the reasons for liquid mold slag entrainment [8]. However, because of the high temperatures and lack of transparency of the phases (liquid steel, liquid slag) and equipment, the direct observation of liquid slag behavior and its stability in the industrial CSC process is impossible. For this reason, alternative methods have been developed to study the impact of casting conditions on the stability of the liquid mold slag phase, which include mathematical $[9,10]$ and physical modeling [11-13].

The purpose of this work was the physical modeling of liquid slag behavior in a CSC mold dependent on the conditions of slab casting: submerged entry nozzle (SEN) geometry, submergence depth of the SEN, and casting speed.

\section{Characteristic of the investigated object}

The object of study was a laboratory model of a mold and SEN intended for the casting of $1.5 \times 0.22 \mathrm{~m}$ cross-section steel slabs. The model is made on reduced linear scale $S_{I}=0.4$. The laboratory station allows us to simulate the steel flow and slag behavior using substitute fluids for this purpose: water and oil, respectively. The kinematic viscosity of molten steel and water at room temperature is similar, so both fluids behave similarly under turbulent flows conditions. 
The dynamic similarity between an industrial system and a laboratory one is satisfied by the Froude criterion:

$$
F r=\left(\frac{u^{2}}{g L}\right)_{\text {laboratory_model }}=\left(\frac{u^{2}}{g L}\right)_{\text {industrial_mold }},
$$

where:

$u$ - fluid flow velocity,

$g$ - gravitational acceleration,

$L$ - characteristic length.

During the continuous casting process, the steel is kept in the mold at a level of $0.9 \mathrm{~m}$. The same is the filling level in the mold model; thus, the model includes both the steel volume in the mold and also in the 1.35-m-length secondary cooling zone. In this paper, two geometries of the SEN model were considered; these are presented in Figure 1. Both SEN models are made of ABS polymer with the use of 3D printing technology. The SENs have two side-ports, inclined $15^{\circ}$ downward in relation to the cross-section of the SEN, whose task is to deliver and direct the stream directly into the mold. The mountain shape of the bottom is used in both SENs. The only difference between the two SENs is the port area: SEN 2 has a 25\% larger port area as compared to SEN 1.

a)

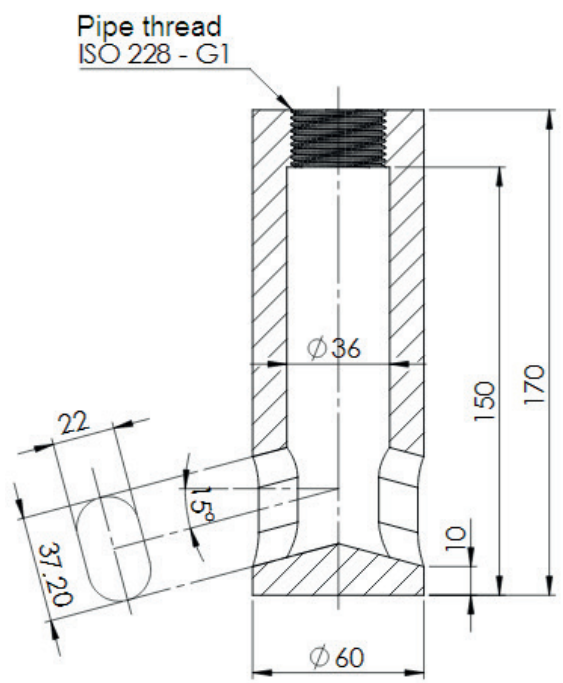

b)

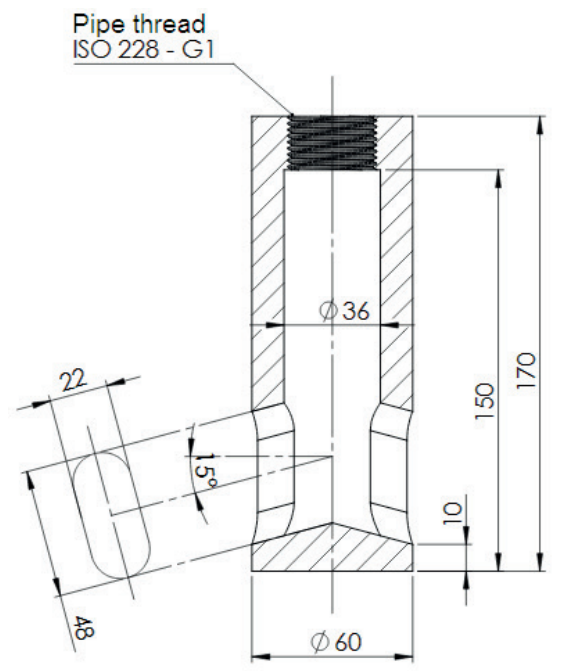

Fig. 1. Characteristic dimensions of SENs: a) SEN 1; b) SEN 2 
The laboratory station is equipped with a system of auxiliaries, including a tank for the water and marker, an electromagnetic flow-meter, an electronically controlled valve, hydraulic connections, and an automatic system of water flow control. The scheme of the laboratory system along with the marked fluid flow directions are presented in Figure 2. In Figure 3, a photograph of the laboratory model during an experiment is shown.

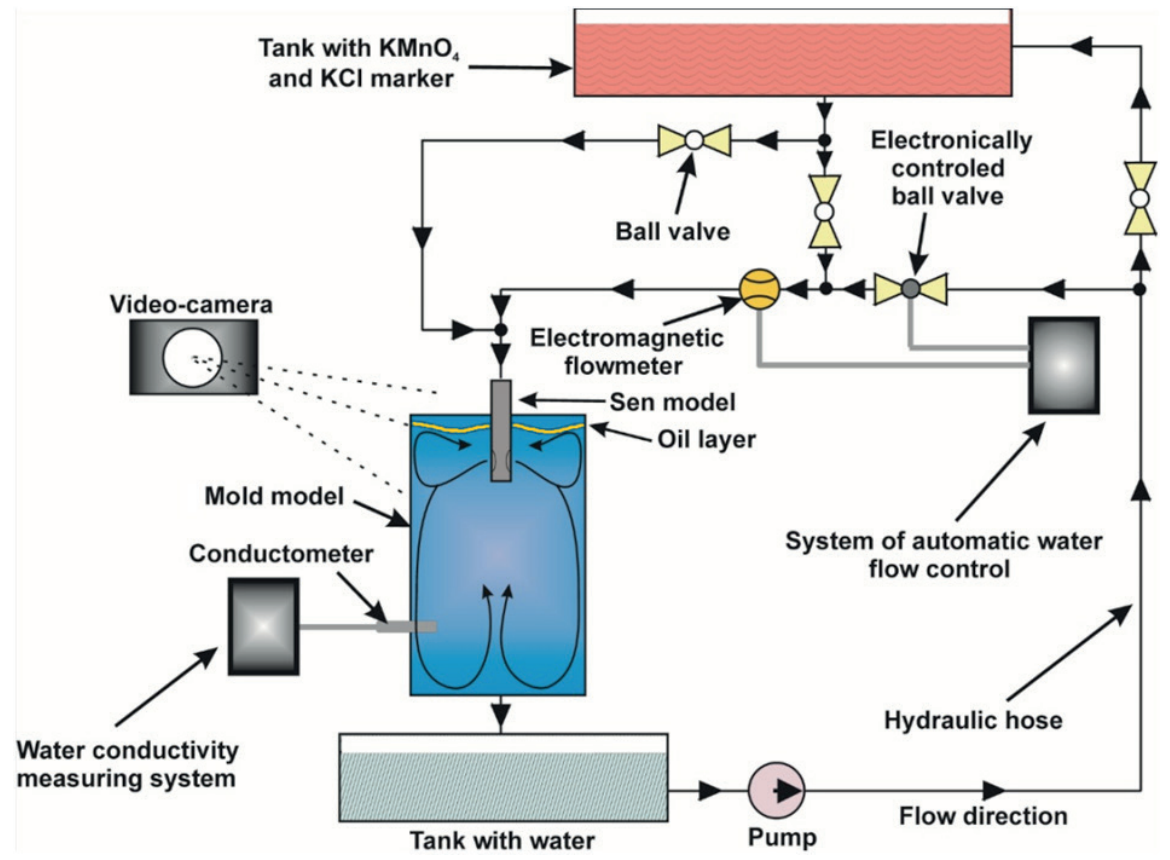

Fig. 2. Scheme of laboratory system

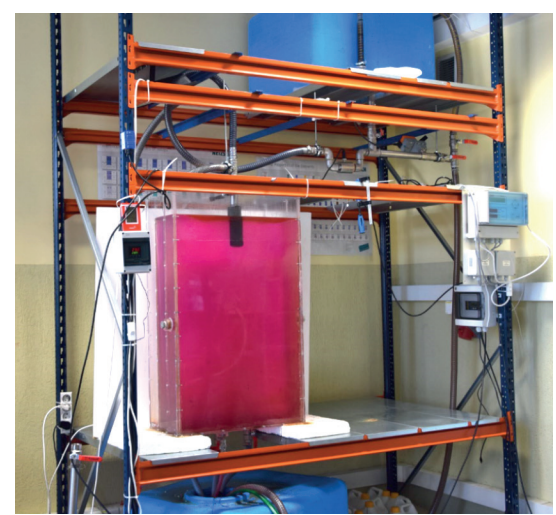

Fig. 3. View of laboratory station during experiment 


\section{Research methodology}

The purpose of the experiments was to investigate the effect of the SEN geometry and casting variables: the submergence depth of the SEN and casting speed on the shape and stability of the liquid slag phase in a mold. Due to the limitations resulting from the model's construction, some simplifications were adopted; thus, the solidification process and oscillatory motion of the mold was not modeled. The presence of mold powder and argon gas was also not considered. Two extreme values of the submergence depth and casting speed used under CSC conditions were taken into account; respectively, 0.215 and $0.295 \mathrm{~m}$ for the submergence depth and 1.0 and $1.6 \mathrm{~m} / \mathrm{min}$ for the casting speed. By applying the criteria of geometric and dynamic similarity as well as the continuity law, the industrial conditions can be converted to experimental conditions. After the conversion, four variants of the experiment (listed in Table 1) were obtained.

Table 1. Values of factors included in laboratory experiments

\begin{tabular}{|l|c|c|}
\hline \multicolumn{1}{|c|}{ Factor } & Lower level & Higher level \\
\hline SEN submergence depth $[\mathrm{m}]$ & 0.086 & 0.118 \\
\hline Water flow rate $[1 / \mathrm{min}]$ & 33.4 & 53.4 \\
\hline
\end{tabular}

The fluid, that will reflect the liquid mold slag should be selected in such a way that Equation (2) will be fulfilled [14]:

$$
\frac{v_{\text {liquid_slag }}}{v_{\text {liquid_steel }}}=\frac{v_{\text {oil }}}{v_{\text {water }}}
$$

With respect to Equation (2) and the range of the kinematic viscosities and densities of the liquid mold slags (respectively, 0.03-2 Pa.s and 2200-2700 kg/m $\mathrm{m}^{3}$ [15], the silicone oil with a dynamic viscosity of $0.1205 \mathrm{~Pa} \cdot \mathrm{s}$ and density equal to $964 \mathrm{~kg} / \mathrm{m}^{3}$ was selected to simulate the liquid mold slag. In all experiments, the oil layer thickness was equal to $0.02 \mathrm{~m}$. After setting the experiment parameters according to Table 1, the flow was developed and stabilized for a time period equal to twice of mean residence time of water volume in the mold model, after which the oil layer was recorded by a video camera (both in the side view and from the top of the mold model). In order to avoid excessive viscosity changes of the water and oil due to the temperature changes, the water temperature was maintained within a range of $16.0-18.0^{\circ} \mathrm{C}$. An identical set of experiments was carried out for the two SENs.

\section{Results}

Figure 4 illustrates the instantaneous shape of the oil layer according to the experiment conditions listed in Table 1 for SEN 1 in the side view of the mold model. 
a)

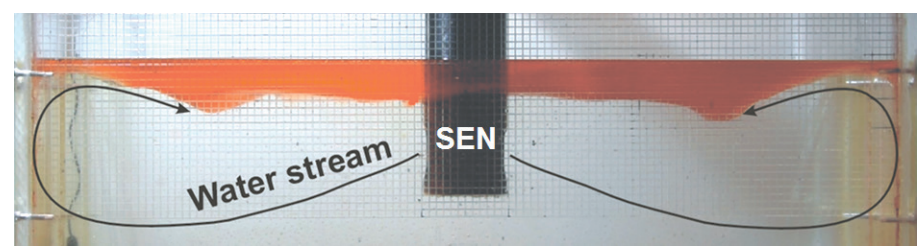

b)

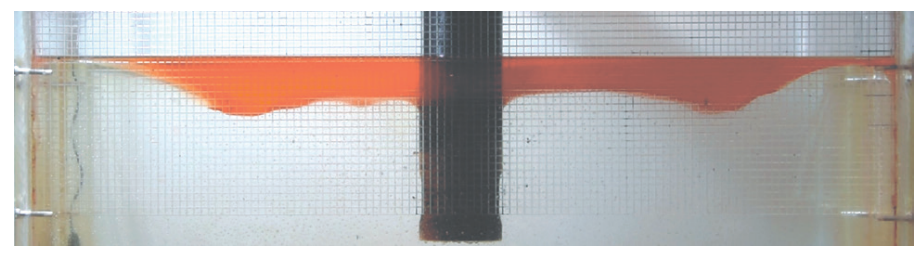

c)

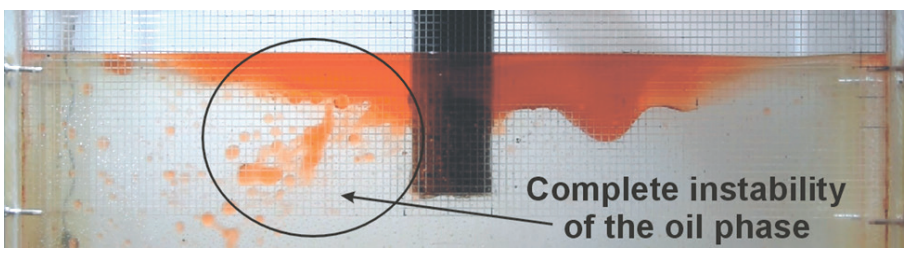

d)

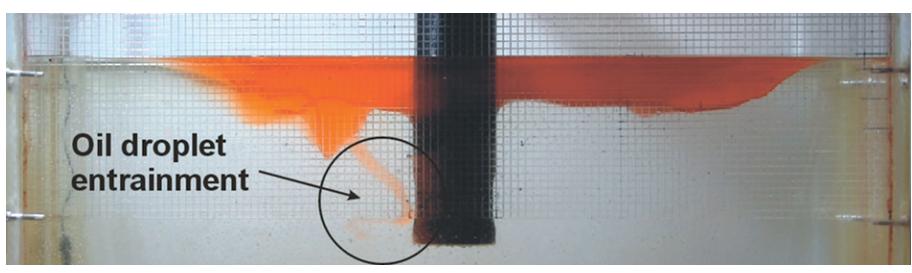

Fig. 4. Instantaneous shape of oil layer observed in experiments carried out using SEN 1: a) submergence depth $-0.086 \mathrm{~m}$, water flow rate $-33.4 \mathrm{l} / \mathrm{min} ; b$ ) submergence depth $-0.118 \mathrm{~m}$, water flow rate - $33.4 \mathrm{l} / \mathrm{min}$; c) submergence depth $-0.086 \mathrm{~m}$, water flow rate $-53.4 \mathrm{l} / \mathrm{min}$; d) submergence depth $-0.118 \mathrm{~m}$, water flow rate $-53.4 \mathrm{l} / \mathrm{min}$

For a SEN submergence depth equal to $0.086 \mathrm{~m}$ and a water flow rate set at $33.4 \mathrm{l} / \mathrm{min}$, the oil layer is stable but distorted as a result of the water stream flow. The local thinning near the narrow faces of the mold model and the bulging halfway between the wall of the SEN and mold narrow face is visible (Fig. 4a). The similar shape of the oil layer was observed when the SEN was submerged to a depth equal to $0.118 \mathrm{~m}$ (Fig. 4b). However, a quite different picture was obtained when the submergence depth was $0.086 \mathrm{~m}$ and the water flow rate was increased to $53.4 \mathrm{l} / \mathrm{min}$. The complete instability of the oil phase was observed, as indicated in Figure 4c. The oil phase was dispersed and emulsified in the whole volume of the mold model. Such casting conditions emphatically cannot be 
used in steelworks, because they will lead to a significant reduction of slab cleanliness as a result of the accumulation of a great number of non-metallic slag-source inclusions. Also, when the SEN submergence is deeper (equal to $0.118 \mathrm{~m}$ ) and the water flow rate is $53.4 \mathrm{l} / \mathrm{min}$, oil droplet entrainment was observed as a result of oil elongation (Fig. $4 \mathrm{~d}$ ). Although the oil entrainment is not as extreme as that illustrated in Figure 4c, such casting conditions are also not recommended in steelworks.

Figure 5 illustrates the instantaneous shape of the oil layer according to the experiment conditions listed in Table 1 for SEN 2 in the side view on the mold model.

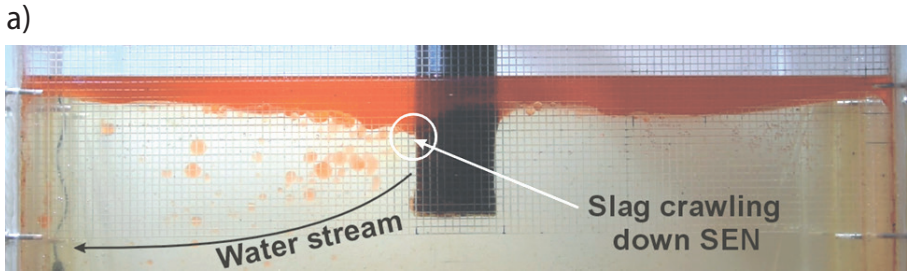

b)

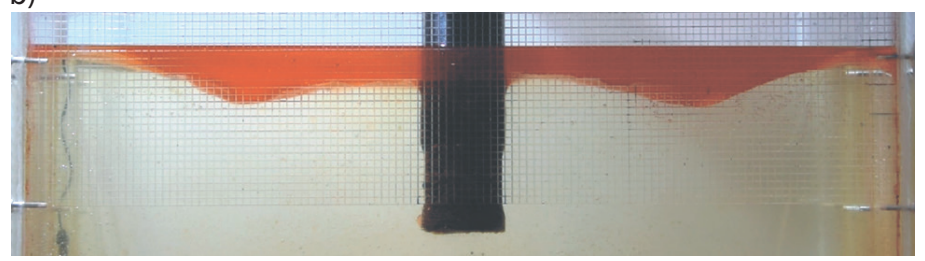

c)

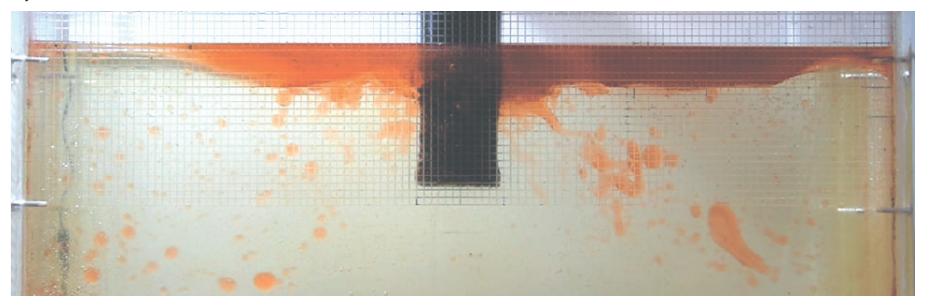

d)

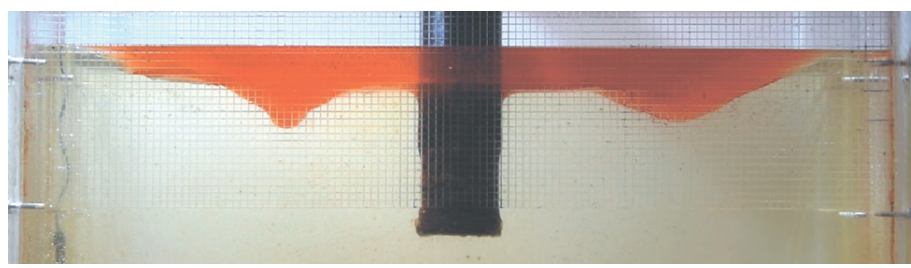

Fig. 5. Instantaneous shape of oil layer observed in experiments carried out using SEN 2: a) submergence depth $-0.086 \mathrm{~m}$, water flow rate $-33.4 \mathrm{l} / \mathrm{min}$; b) submergence depth $-0.118 \mathrm{~m}$, water flow rate $-33.4 \mathrm{l} / \mathrm{min}$; c) submergence depth $-0.086 \mathrm{~m}$, water flow rate $-53.4 \mathrm{l} / \mathrm{min}$; d) submergence depth $-0.118 \mathrm{~m}$, water flow rate $-53.4 \mathrm{l} / \mathrm{min}$ 
Figure 5a illustrates the behavior of the oil layer when the SEN submergence depth is $0.086 \mathrm{~m}$ and the water flow rate is $33.4 \mathrm{I} / \mathrm{min}$. It is visible that the oil adheres to the wall of the SEN and then crawls down it. When the oil reaches the area occupied by the ports, it is sheared and dispersed in the water volume by a water stream. For the same experimental conditions, the oil layer was stable when SEN 1 was used. The explanation for this fact is that the port height of SEN 1 is smaller, so the distance between the oil layer and feeding stream is larger. The oil would have to be more distorted to be cut off by the water stream. When the SEN submergence depth was $0.118 \mathrm{~m}$ and the water flow rate was set at a lower level, the shape of the oil is similar to when SEN 1 was used (compare Figures $4 \mathrm{~b}$ and $5 \mathrm{~b}$ ). Also, when the submergence depth of the SEN was equal to $0.086 \mathrm{~m}$ and the water flow rate was $53.4 \mathrm{l} / \mathrm{min}$, a total instability of the oil was observed (Fig. 5c), just like using SEN 1. However, at a deeper SEN submergence, the oil layer was stable (Fig. 5d), which is contrary to SEN 1 (Fig. 4d).

Figure 6 illustrates the instantaneous shape of the oil layer according to the experiment conditions listed in Table 1 for SEN 1 observed from the top of the mold model. The photographs show a maximum observed distortion of the oil layer. To qualitatively determine the degree of oil phase distortion, a ruler was plotted in the Figure starting from the mold narrow face up to the wall of the SEN.

a)

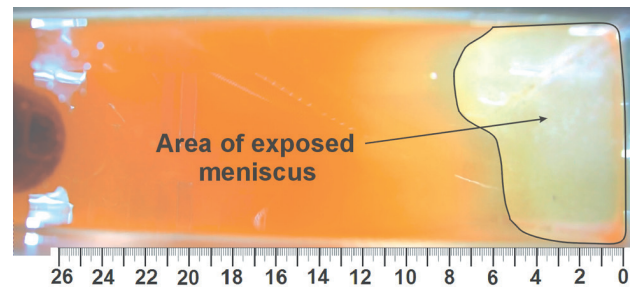

c)

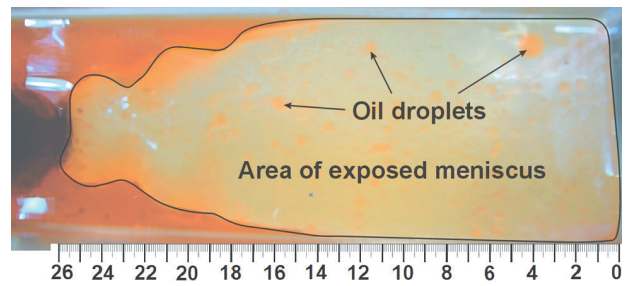

b)

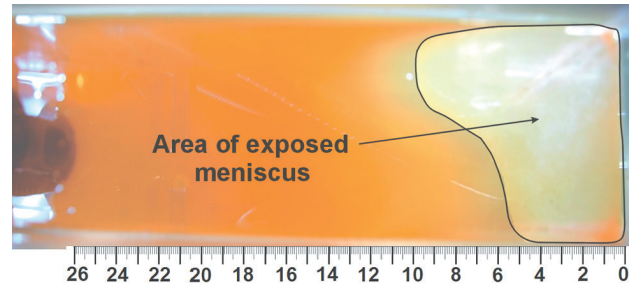

d)

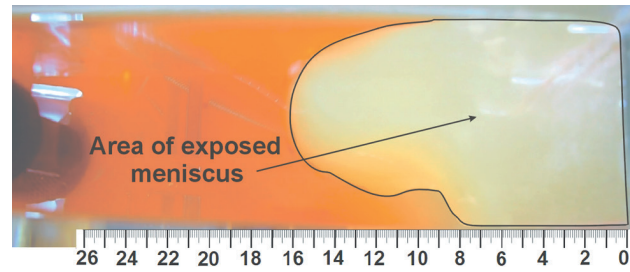

Fig. 6. Instantaneous shape of oil layer observed in experiments carried out using SEN 1 - view from top of mold model: a) submergence depth $-0.086 \mathrm{~m}$, water flow rate $-33.4 \mathrm{l} / \mathrm{min} ; \mathrm{b}$ ) submergence depth $-0.118 \mathrm{~m}$, water flow rate $-33.4 \mathrm{l} / \mathrm{min}$; c) submergence depth $-0.086 \mathrm{~m}$, water flow rate $-53.4 \mathrm{l} / \mathrm{min}$; d) submergence depth $-0.118 \mathrm{~m}$, water flow rate $-53.4 \mathrm{l} / \mathrm{min}$ 
Regardless of the experimental conditions, the water meniscus was exposed to air. For a water flow rate equal to $33.4 \mathrm{l} / \mathrm{min}$, the exposed meniscus occupies the area near the narrow face of the mold model. For the greater submergence depth of the SEN, the maximum area of the exposed meniscus is slightly larger than that for the smaller submergence depth (Figs. $6 \mathrm{a}$ and $6 \mathrm{~b}$ ). When the water flow rate is set as $53.4 \mathrm{l} / \mathrm{min}$ and the submergence depth of the SEN is equal to $0.086 \mathrm{~m}$, the area of the meniscus "balding" extends up to the wall of the SEN. Moreover, a lot of oil droplets are visibly circulating in the water volume (as indicated by the arrows in Figure $6 c$ ). When the submergence of the SEN is deeper at the same water flow rate, the area of the exposed meniscus is visibly smaller, but it still occupies approximately half of the total cross-section of the mold model (Fig. 6d).

Figure 7 shows the instantaneous shape of the oil layer in the view from the top of the mold model according to the experiment conditions listed in Table 1 for SEN 2.

a)

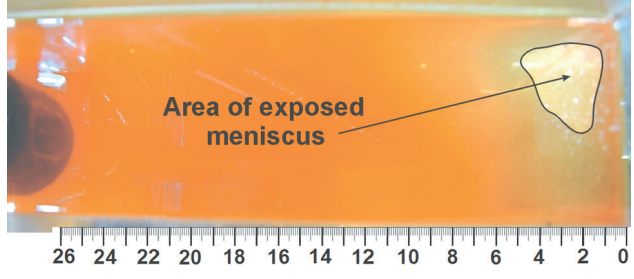

c)

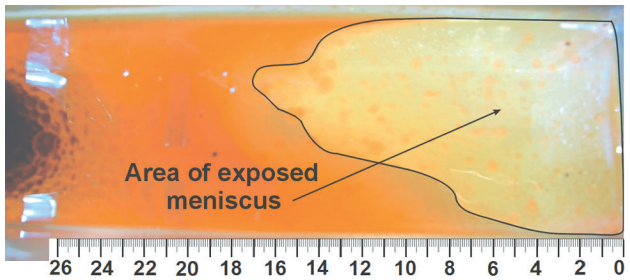

b)

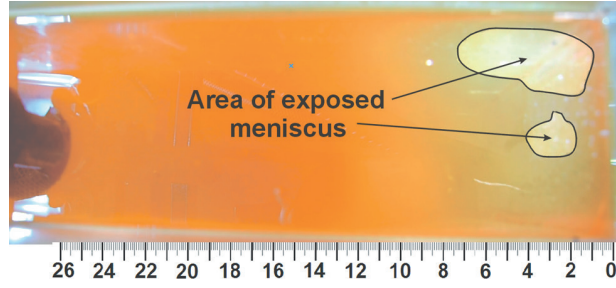

d)

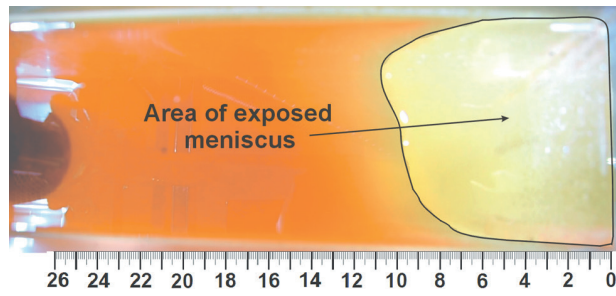

Fig. 7. Instantaneous shape of oil layer observed in experiments carried out using SEN 2 - view from top of mold model: a) submergence depth $-0.086 \mathrm{~m}$, water flow rate $-33.4 \mathrm{l} / \mathrm{min}$; b) submergence depth $-0.118 \mathrm{~m}$, water flow rate $-33.4 \mathrm{l} / \mathrm{min}$; c) submergence depth $-0.086 \mathrm{~m}$, water flow rate $-53.4 \mathrm{l} / \mathrm{min}$; d) submergence depth $-0.118 \mathrm{~m}$, water flow rate $-53.4 \mathrm{l} / \mathrm{min}$

When SEN 2 was used in the experiments, the meniscus "balding" phenomenon also occurred in all variants of the experiments; however, the area of the exposed meniscus is clearly smaller than with the use of SEN 1. At a water flow rate of $33.4 \mathrm{l} / \mathrm{min}$ and SEN submergence depth equal to $0.086 \mathrm{~m}$, the exposed meniscus occupies a relatively small area near the narrow face of the mold model (Fig. 7a). For the deeper SEN submergence, there are two areas of meniscus "balding" (Fig. 7b). A much larger area of the exposed meniscus was observed at a water flow rate equal to $53.4 \mathrm{l} / \mathrm{min}$ and SEN submergence 
depth equal to $0.086 \mathrm{~m}$ (Fig. 7c). You can also see many oil droplets circulating in the volume of water (similar to when SEN 1 was used). For the greater SEN submergence, the area of the exposed meniscus is smaller and extends up to approx. $0.11 \mathrm{~m}$ from narrow face of the mold model.

To investigate the effect of the SEN geometry on the flow structure in the mold at a water flow rate equal to $33.4 \mathrm{I} / \mathrm{min}$ and SEN submergence depth equal to $0.118 \mathrm{~m}$, the hydrodynamic structure was visualized by marker injection (an aqueous solution of $\mathrm{KMnO}_{4}$ ) to the SEN model. The sequences of photos that illustrate the marker dispersion in the water volume at the characteristic time moments for SEN 1 and SEN 2 are presented in Figure 8 and Figure 9, respectively.

a)

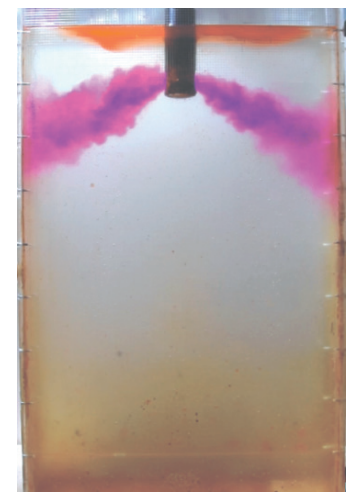

b)

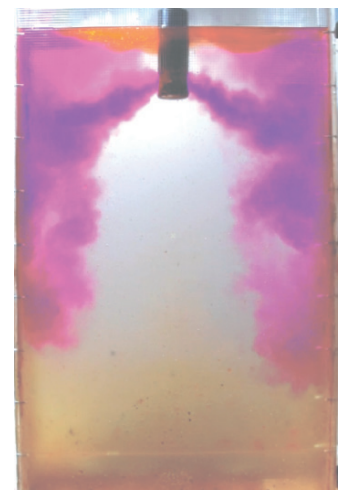

c)

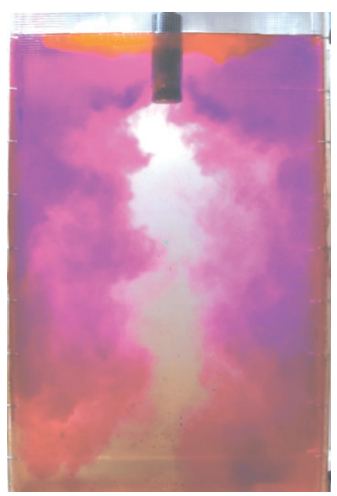

Fig. 8. Visualization of water flow structure in mold model after: a) $1 \mathrm{~s}$; b) $3 \mathrm{~s}$; c) $6 \mathrm{~s}$ from marker injection. SEN 1 - water flow rate equal to $33.41 / \mathrm{min}$ and SEN-submergence depth equal to $0.118 \mathrm{~m}$

a)

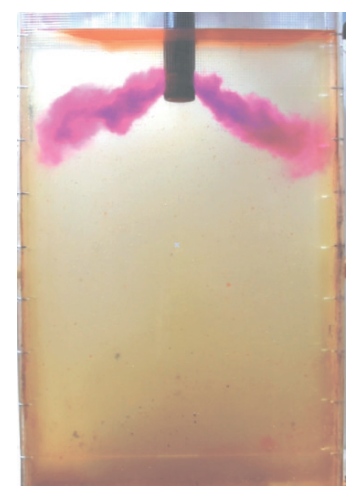

b)

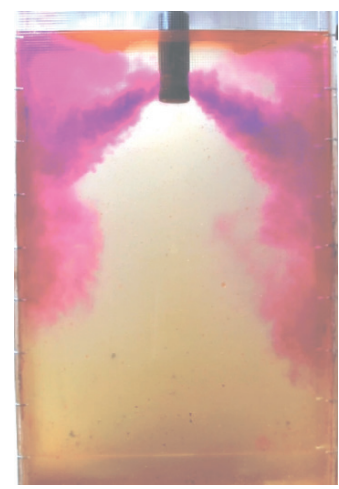

c)

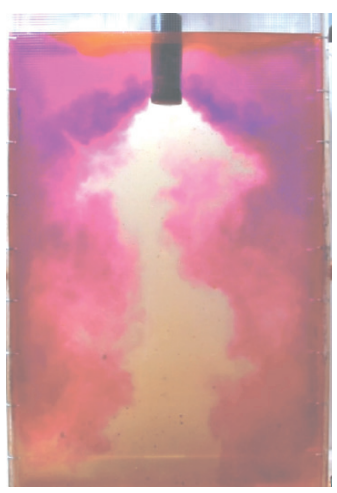

Fig. 9. Visualization of water flow structure in mold model after: a) $1 \mathrm{~s}$; b) $3 \mathrm{~s}$; c) 6 s from marker injection. SEN 2 - water flow rate equal to $33.41 / \mathrm{min}$ and SEN - submergence depth equal to $0.118 \mathrm{~m}$ 
The general hydrodynamic structure forming in the volume of the mold model is similar for both SENs. After hitting the narrow face of the mold model, the main water stream is split into two streams, forming two recirculation zones that are different in flow direction. Thus, the hydrodynamic structure should be classified as the classic Double Roll Flow pattern [16]. The marker distribution after one second from the marker injection indicates that the water main streams move faster when SEN 1 is used: the main water streams are already starting to divide in the experiment case with SEN 1 (Fig. 8a), whereas in the experiment case with SEN 2, the water main streams have not touched the mold narrow face as of yet (Fig. 9a).The higher velocities of the water streams cause that more momentum is transferred to the oil layer. This explains why the area of the exposed meniscus was larger when SEN 1 was used. The flow velocity increase with the reduction of the nozzle port area is also confirmed by the results of the numerical simulations [17].

A summary of the laboratory test results is presented in Table 2 and Table 3, where it is specified whether the CSC for the given casting conditions is allowed or should be avoided. The SEN submergence depths and casting speeds have been calculated based on the conditions of the experiments with respect to the principles of the similarity theory and continuity law. The casting is allowed when liquid slag entrainment will not occur.

Table 2. Specification of acceptable casting conditions for SEN 1

\begin{tabular}{|c|c|c|}
\hline \multirow{2}{*}{ Casting speed [m/min] } & \multicolumn{2}{|c|}{ SEN submergence depth [m] } \\
\cline { 2 - 3 } & $\mathbf{0 . 2 1 5}$ & $\mathbf{0 . 2 9 5}$ \\
\hline 1.0 & $\checkmark$ & $\checkmark$ \\
\hline 1.6 & $\mathrm{X}$ & $\times$ \\
\hline
\end{tabular}

Table 3. Specification of the acceptable casting conditions for SEN 2

\begin{tabular}{|c|c|c|}
\hline \multirow{2}{*}{ Casting speed [m/min] } & \multicolumn{2}{|c|}{ SEN submergence depth [m] } \\
\cline { 2 - 3 } & $\mathbf{0 . 2 1 5}$ & $\mathbf{0 . 2 9 5}$ \\
\hline 1.0 & $\checkmark$ & $\checkmark$ \\
\hline 1.6 & $\times$ & $\times$ \\
\hline
\end{tabular}

\section{Conclusions}

Experimental tests of the continuous casting of steel slabs in a mold were carried out. The effect of the submerged entry nozzle (SEN) geometry, submergence depth of the SEN, and casting speed on the shape and stability of the liquid mold slag layer was evaluated. 
Based on the results and their discussion, the following conclusions should be drawn.

- Using SEN 1, it is not recommended to cast with a speed equal to $1.6 \mathrm{~m} / \mathrm{min}$. For this casting condition, instabilities of the liquid slag layer may occur.

- Using SEN 2, it is not recommended to cast when the submergence depth of the SEN is equal to $0.086 \mathrm{~m}$. For this casting condition, instabilities of the liquid slag layer may occur.

- Regardless of the conditions of the experiments, the water meniscus was exposed to air. The area of the exposed meniscus was larger when SEN 1 was used.

- The general hydrodynamic structure is similar for both nozzles. However, the water main streams moved faster when SEN 1 was used.

\section{Acknowledgements}

For National Science Centre, Poland, for the financial support within the framework of research project PRELUDIUM 9 no. 2015/17/N/ST8/02138.

\section{References}

[1] Steel Statistical Yearbook 2017. www.worldsteel.org [07.02.2018]

[2] Jeon Y.J., Sung H.J., Lee S.: Flow Oscillations and Meniscus Fluctuations in a Funnel-type Water Mold Model. Metallurgical and Materials Transactions B, 41, 1 (2010), 121-130

[3] Torres-Alonso E., Morales R.D., García-Hernández S., Palafox-Ramos J.: Cyclic Turbulent Instabilities in a Thin Slab Mold. Part I: Physical Model. Metallurgical and Materials Transactions B, 41, 3 (2010), 583-597

[4] Morales R.D., Tang Y., Nitzl G., Eglsäeer C., Hackl G.: Design of a Submerged Entry Nozzle for Thin Slab Molds Operating at High Casting Speeds. ISIJ International, 52, 9 (2012), 1607-1615

[5] Arcos-Gutierrez H., Barrera-Cardiel G., Barreto J. de J., Garcia-Hernandez S.: Numerical Study of Internal SEN Design Effects on Jet Oscillations in a Funnel Thin Slab Caster. ISIJ International, 54, 6 (2014), 1304-1313

[6] Suzuki M., Suzuki M., Nakada M.: Perspectives of Research on High-speed Conventional Slab Continuous Casting of Carbon Steels. ISIJ International, 41, 7 (2001), 670-682

[7] Li L.-P., Wang X.-H., Deng X.-X., Ji C.-X.: Process and Quality Control during High Speed Casting of Low Carbon Conventional Slab. Journal of Iron and Steel Research International, 22, Supplement 1 (2015), 1-9

[8] Zhang L., Yang S., Cai K., Li J., Wan X., Thomas B.G.: Investigation of Fluid Flow and Steel Cleanliness in the Continuous Casting Strand. Metallurgical and Materials Transactions B, 38, 1 (2007), 63-83

[9] Bielnicki M., Jowsa J., Cwudziński A.: Multiphase Numerical Model of Molten Steel and Slag Behavior in the Continuous Casting Mould. Archives of Metallurgy and Materials, 60, 1 (2015), 257-262

[10] Jowsa J., Bielnicki M., Cwudziński A.: Numerical Modeling of Metal/Flux Interface in a Continuous Casting Mould. Archives of Metallurgy and Materials, 60, 4 (2015), 2905-2912

[11] Wang Z., Mukai K., Ma Z., Nishi M., Tsukamoto H., Shi F.: Influence of Injected Ar Gas on the Involvement of the Mold Powder under Different Wettabilities between Porous Refractory and Molten Steel. ISIJ International, 39, 8 (1999), 795-803

[12] Calderon-Ramos I., Barreto J. de J., Garcia-Hernandez S.: Physical and Mathematical Modelling of Liquid Steel Fluidynamics in a Billet Caster. ISIJ International, 53, 5 (2013), 802-808 
[13] Morales-Higa K., Guthrie R.I.L., Isac M., Morales R.D., Labrecque C., Lapointe F.: A Comparative Study of Multiport Nozzles in a Square Billet Mold. $8^{\text {th }}$ European Continuous Casting Conference, Graz, Austria 23-26.06.2014. The Austrian Society of Metallurgy and Materials, 2014, 477-486

[14] Jin X., Chen D.F., Xie X., Shen J., Long M.: Investigation on Water Model for Fluid Flow in Slab Continuous Casting Mold with Consideration of Solidified Process. Steel Research International, 84, 1 (2013), 31-39

[15] Mills K.C.: Structure and Properties of Slags Used in the Continuous Casting of Steel. Part 1: Conventional Mould Powders. ISIJ International, 56, 1 (2016), 1-13

[16] Calderón-Ramos I., Morales R.D., Garcia-Hernandez S., Ceballos-Huerta A.: Effects of Immersion Depth on Flow Turbulence of Liquid Steel in a Slab Mold Using a Nozzle with Upward Angle Rectangular Ports. ISIJ International, 54, 8 (2014), 1797-1806

[17] Najjar F.M., Thomas B.G., Hershey D.E.: Numerical Study of Steady Turbulent Flow through Bifurcated Nozzles in Continuous Casting. Metallurgical and Materials Transactions B, 26, 4 (1995), 749-765 